\title{
Surgical Management of the Retained Epidural Catheter Fragment Complicated by Postoperative Phlegmon
}

\author{
Tina M Yu, Mastoora Nasiri and Solmaz P Manuel* \\ ${ }^{1}$ Department of Anesthesia and Perioperative Care, University of California, USA
}

Submission: : December 28, 2017; Published: February 05, 2018

*Corresponding author: Solmaz P Manuel, Department of Anesthesia and Perioperative Care, University of California, 500 Parnassus Avenue, MU West 4th Floor, Box 0648, CA 94143, San Francisco, USA, Tel: (415) 476-9043, Email: Solmaz.Manuel@ucsf.edu

\begin{abstract}
Lumbar epidurals are an effective form of labor pain control. The breakage of an epidural catheter is an extremely rare complication. No clear management guidelines or algorithms exist for retained epidural fragments or entrapped catheters. Here we report a case of fractured and retained epidural catheter after uncomplicated placement with Dural puncture for confirmation of midline placement, the imaging done to locate the fragment, the decision to surgically remove the fragment, and subsequent surgical bed infection. We review the management options for difficult to remove epidural catheters, the optimal methods of locating the retained fragments, and the indications for surgical removal.
\end{abstract}

Keywords: Retained epidural catheter, Fractured catheter, Neuraxial complications, postoperative complications, Surgical intervention

\section{Introduction}

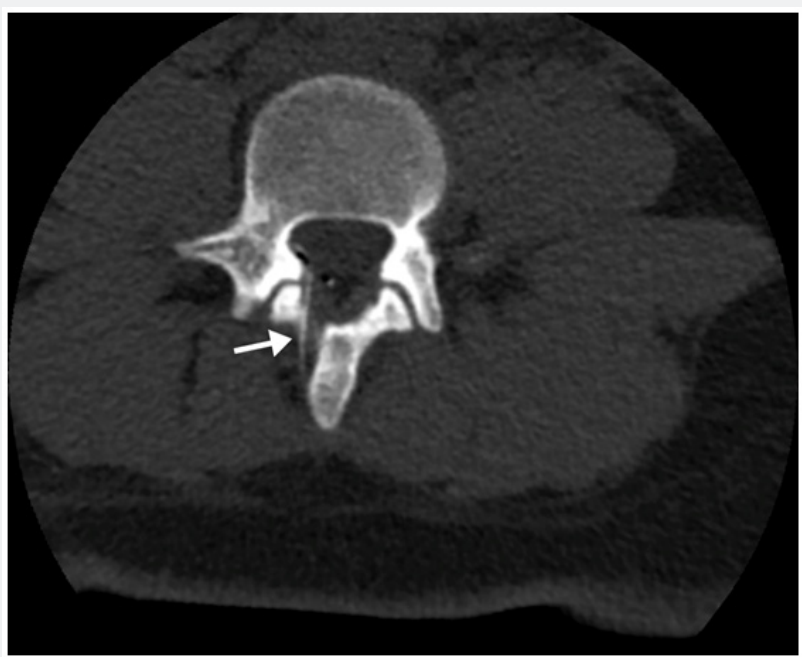

Figure 1: Retained epidural catheter extending along the rightward aspect of the L3 spinous process.

A 20-year-old woman gravida 2 para 1 at $40+1$ week's gestation presented in spontaneous labor and requested an epidural for labor analgesia. After sterile preparation, the L3-4 epidural space was identified at $6 \mathrm{~cm}$ using saline loss of resistance technique with Dural puncture confirming midline placement. An Arrow Flex Tip Plus 19g catheter (Arrow International Inc., Reading, PA) was advanced without resistance and secured $11 \mathrm{~cm}$ at the skin. Following uncomplicated vaginal delivery, catheter removal was attempted seven hours after placement. Resistance was felt while applying usual traction and the catheter snapped leaving a $7 \mathrm{~cm}$ retained fragment. Subsequent computed tomography (CT) imaging showed the catheter fragment extending along the rightward aspect of the L3 spinous process before looping in the posterior epidural space and terminating at the L3-L4 level (Figure 1).

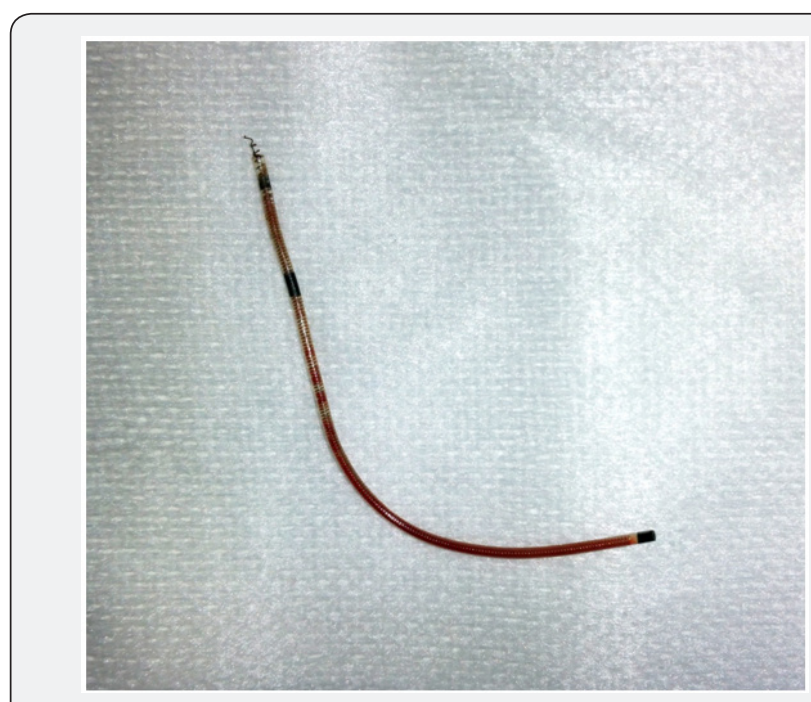

Figure 2: Distal end of fractured epidural catheter after removal.

Neurosurgery was consulted and while no neurologic deficit was noted, the decision was made to remove the catheter fragment due to patient concerns for future infection and development 
of scar or granulation tissue in the epidural space. Post-partum day one she underwent an uncomplicated L3-L4 laminectomy with successful removal of the catheter fragment located on the right lateral aspect of the cal sac (Figure 2). Two months later she noted purulent drainage from her back and imaging showed phlegmon in the posterior spinal surgical bed extending into the dorsal epidural space of L2-L4 (Figure 3). Incision, drainage and a course of antibiotics were required to treat Staphylococcus aureus infection.

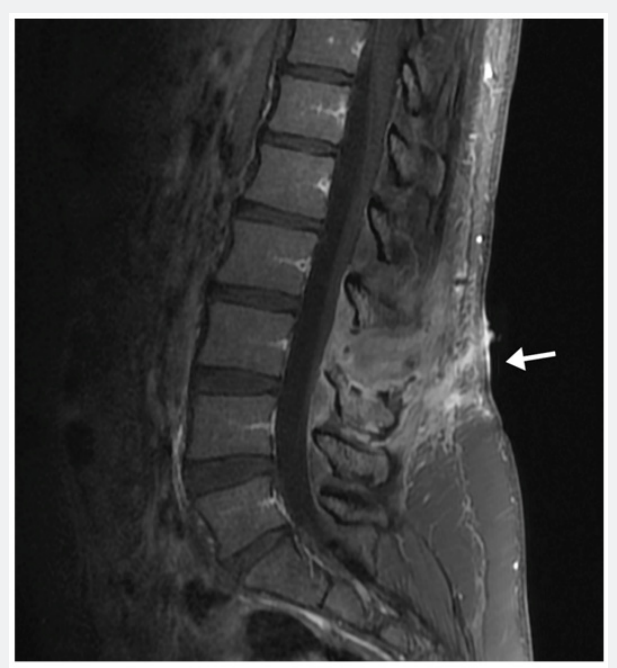

Figure 3: Phlegmon in the posterior surgical bed extending into the dorsal epidural space of L2-L4.

\section{Discussion}

The breakage of epidural catheters with retained fragments is a rare complication. Several mechanisms have been proposed as the cause of epidural catheter breakage, including manufacturing weakness, shearing or nicking of the catheter against the insertion needle, injury of the catheter by spinal needle in two level combined spinal and epidural procedures, knotted catheters, entanglement of catheters with structures in the epidural space such as nerve roots and blood vessels, or entrapment in vertebral processes, facet joints, and semispinalis muscles [1,2]. In addition, postpartum edema may worsen impingement and waiting a few hours for swelling to subside may increase ease of removal [3].

All manufacturers include warnings against excessive or undue force during removal of epidural catheters. The average force required to remove an epidural catheter is $2.04 \mathrm{~N}(\sim 0.459 \mathrm{lb}$ of force) [4]. Arrow brand catheters have been reported to stretch more than other catheter brands and break at lower forces than other brands of epidural catheters, especially at the $5 \mathrm{~cm}$ mark $[5,6]$. Polyurethane catheters are the strongest catheter, whereas radiopaque catheters have the highest elasticity [5]. Multiple strategies have been previously suggested to assist in removal of a stuck epidural catheter (Table 1). Once a catheter has fractured, determining the exact location of the proximal and distal ends is not straightforward. CT has been recommended to locate retained catheters due to high resolution and ease of obtaining the test
[7,8]. Magnetic resonance imaging (MRI) of the spine is not recommended as first diagnostic test of choice for ferromagnetic catheters due to metallic artifact, larger slice size, risk of neural injury secondary to heating of a wire-enforced catheter in the epidural space, and risk of catheter movement [9-11].

Table 1: Strategies to assist in removal of a stuck epidural catheter $[1,3,7,18,19,20,21]$.

\begin{tabular}{|l|}
\hline Apply slow continuous force to the catheter \\
\hline $\begin{array}{l}\text { If the catheter begins to stretch, stop applying force and return several } \\
\text { hours later. }\end{array}$ \\
\hline $\begin{array}{l}\text { Consider tying or wrapping a tongue depressor to the distal end of the } \\
\text { stuck catheter until taut and tape to the back to allow continuous gentle } \\
\text { traction during regular patient activities. }\end{array}$ \\
\hline Attempt removal with the patient in the same position as insertion. \\
\hline $\begin{array}{l}\text { Attemptremoval with the patient in the lateral position, which decreases } \\
\text { resistance and the force required to remove a catheter. }\end{array}$ \\
\hline $\begin{array}{l}\text { Attempt catheter removal with the patient in extreme flexion and } \\
\text { extension. }\end{array}$ \\
\hline Re-attempt removal after patient has been mobile and ambulated. \\
\hline $\begin{array}{l}\text { Attempt removal after an injection of cold preservative free normal } \\
\text { saline through the catheter. }\end{array}$ \\
\hline $\begin{array}{l}\text { Consider use of convex surgical frame, which is thought to allow } \\
\text { relaxation of the paraspinal muscles and spinal ligaments, and allow for } \\
\text { easier catheter removal. }\end{array}$ \\
\hline $\begin{array}{l}\text { Consider using CT scan to identify potential location of entrapment and } \\
\text { guide positioning during removal. }\end{array}$ \\
\hline $\begin{array}{l}\text { Consider inserting a sterile guide wire through the catheter to unkink, } \\
\text { stiffen and aid removal. }\end{array}$ \\
\hline Neurosurgical consultation. \\
\hline
\end{tabular}

The optimal management of retained epidural fragments is debatable. It has been suggested that because retained fragments are sterile and unlikely to cause serious neurological sequelae, it is acceptable for them to be left in situ [7]. Multiple complications have been reported related to retained catheter fragments, however, including catheter tip migration into the intrathecal space with resulting CSF leak [12], nerve entrapment with radicular pain [13], formation of scar tissue around the catheter fragment resulting in spinal stenosis [8], and foraminal stenosis [14], infection [15], and delayed subdural hematoma formation [16-21]. Therefore, even without immediate evidence of neurologic or infectious sequelae, providing patients the option of surgical removal versus watchful waiting is still reasonable $[9,17]$.

\section{Conclusion}

Breakage of epidural catheter is an extremely rare complication following uncomplicated placement. Despite Dural puncture to confirm midline placement, this catheter coursed laterally and became entrapped in the epidural space. Without applying a large amount of force the catheter fractured. The patient's preference to undergo laminectomy for removal was honored, but was complicated by postoperative epidural phlegmon formation. Infection was successfully treated with incision, drainage and a course of antibiotics. 


\section{Funding Sources}

Departmental support only.

\section{Conflicts Of Interest}

None

\section{References}

1. Hajnour MS, Khokhar RS, Ejaz AAA, Zahrani TA, Kanchi NU (2017) Difficulty in the removal of epidural catheter for labor analgesia. Saudi Journal Anesthesia 11(1): 117-119.

2. Sakuma N, Hori M, Suzuki H, Hashimoto Y, Kameyama E, et al. (2004) A sheared off and sequestered epidural catheter: A case report. Masui 53: $198-200$.

3. Pierre HL, Block BM, Wu CL (2003) Difficult removal of a wirereinforced epidural catheter. J Clin Anesth 15(2):140-141.

4. Boey SK, Carrie LE (1994) Withdrawal forces during removal of lumbar extradural catheters. Br J Anaesth 73(6): 833-835.

5. Asai T, Yamamoto K, Hirose T, Taguchi H, Shingu K. (2001) Breakage of epidural catheters: a comparison of an arrow reinforced catheter and other non-reinforced catheters. Anesth Analg 92(1): 246-248.

6. Anwari JS, Al Wahbi Y, Al Nahdi S (2014) A broken catheter in the epidural space. Neurosciences (Riyadh). 19(2): 138-141.

7. Mitra R, Fleischmann K (2007) Management of the sheared epidural catheter: Is surgical extraction really necessary? J Clin Anesth 19(4): 310-314.

8. Staats PS, Stinson MS, Lee RR (1995) Lumbar stenosis complicating retained epidural catheter tip. Anesthesiology 83(5): 1115-1118.

9. Noblett K, McKinney A, Kim R (2007) Sheared epidural catheter during an elective procedure. Obstet Gynecol 109(2 Pt2): 566-568.

10. Sheehan C, Sodhi V (2012) Retained epidural catheter tip. Int J Obstet Anesth 21(4): 389-390.
11. Owens S, Erturk MA, Ouanes JP, Murphy JD, Wu CL, et al. (2014) Evaluation of epidural and peripheral nerve catheter heating during magnetic resonance imaging. Reg Anesth Pain Med 39(6): 534-539.

12. Ugboma S, Au Truong X, Kranzler LI, Rifai SH, Joseph NJ, Salem MR (2002) The breaking of an intrathecally-placed epidural catheter during extraction. Anesth Analg 95(4): 1087-1089.

13. Blanchard N, Clabeau JJ, Ossart M, Dekens J, Legars D, Tchaoussoff J (1997) Radicular pain due to a retained fragment of epidural catheter. Anesthesiology 87:1567-1569.

14. You JW, Cho YH (2010) Foramina stenosis complicating retained broken epidural needle tip - A case report. Korean J Anesthesiology 59(Suppl): 69-72.

15. De Armendi AJ, Ryan JF, Chang HM, Liu LMP, Jaramillo D (1992) Retained caudal catheter in a pediatric patient. Paid Anes 2(4): 325327.

16. Ishikawa Y, Imagama S, Ito Z, Ando K, Gotoh M, et al. (2016) Delayed onset of subdural hematoma following epidural catheter breakage. Global Spine J 6(1): e1-e6.

17. Tarukado K, Oda T, Tono O, Suetsugu H, Doi T (2015) A Retained Epidural Catheter Fragment Treated by Surgery. Asian Spine J 9(3): 461-464.

18. Ben David B (2002) Complications of regional anesthesia: An overview. Anesthesiol Clin North America 20(3): 665-667.

19. Gravenstein N, Blackshear RH, Wissler RN (1991) An approach to spinal or epidural catheters that are difficult to remove. Anesthesiology 75(3): 544.

20. Morris GN, Warren BB, Hanson EW, Mazzeo FJ, DiBenedetto DJ (1996) Influence of patient position on withdrawal forces during removal of lumbar extradural catheters. Br J Anaesth 77(3): 419-420.

21. Schummer W, Schummer C (2002) Another cause of epidural catheter breakage? Anesth Analg 94(1): 233.

\section{Your next submission with Juniper Publishers} will reach you the below assets

- Quality Editorial service

- Swift Peer Review

- Reprints availability

- E-prints Service

- Manuscript Podcast for convenient understanding

- Global attainment for your research

- Manuscript accessibility in different formats

( Pdf, E-pub, Full Text, Audio)

- Unceasing customer service

Track the below URL for one-step submission https://juniperpublishers.com/online-submission.php 